$$
\begin{aligned}
& \text { 多層ラミネートフィルムの衝撃引張挙動におよぼす } \\
& \text { 瓶口シール部形状の影響十 } \\
& \text { 青木 博 之*島本 } \\
& \text { 二 瀬 克 規* 鎌 田幸 彦* }
\end{aligned}
$$

\title{
Effect of the Sealing Form in Flexible Bottle Neck upon Impact Tensile Behavior of Multi Layer Laminate Film
}

by

\author{
Hiroyuki AoкI ${ }^{*}$, Akira Shimamoto ${ }^{* *}$, Katsunori FutaSE ${ }^{*}$ and Yukihiko Kamada ${ }^{*}$
}

\begin{abstract}
The bottle-neck shaped seal of bags for holding liquid is particularly convenient for pouring the liquid into another container. In recent years, bags have frequently broken at the bottle-neck shaped seal because the bags were subjected to the impact during loading and unloading. Taking this into consideration, we performed impact tensile tests using two types of bags with bottle-neck shaped seals, one with barrier characteristics, i.e., laminate films of NY/alumina-evaporation PET/XA-S and NY/AL/XA-S, and one without barrier characteristics, i.e., NY/XA-S for bottle neck shaped seal diameters of $7.5,10,12.5,13,14,15$ and $20 \mathrm{~mm}$ and flat seal bags. When the seal diameter of NY/aluminaevaporation PET/XA-S, NY/AL/XA-S or NY/XA-S is $15 \mathrm{~mm}$ or greater, the impact tensile load at break is almost the same as that of flat seal bags.
\end{abstract}

Key words : Impact tensile testing, Liquid package bag, Composite materials, Infrared thermography, Extrusion

\section{1 緒言}

液体の流通には缶，瓶，ペットボトル，液体包装袋 (フレキシブルパッケージ) など様々な容器がある。中で も少容量の液体パッケージは瓶, ペットボトル，プラスチ ック成形容器等のハードパッケージに比し，プラスチック フィルムを多層化したラミネートフィルムによる液体包 装袋が多く利用されている。特に, 液体包装袋はハード パッケージに比して機能性, 経済性に優れ, プラスチッ クの減肉化ができ省資源の面からも環境負荷低減の効果 が期待出来る。しかし使用されているプラスチックは非 常に薄い単一フィルムを貼り合わせているため, 荷造り 時や，運搬および積み降ろし時の衝撃荷重によって，破 袋（袋が破机ること）が起き易い. 先に著者ら ${ }^{1) １ 1 ） は ラ ~}$ ミネートフィルムのヒートシール部の衝撃引張力について 明らかにした。近年, 瓶口シール部形状は平シールに比 して内容物をそそぎ易く便利であることから，平シールに 代わり瓶口シール部形状のシールが多く用いられるよう になってきた。その反面通常の平シールに比して瓶口 シール部からの破袋が多く発生しているのが現状である. 本研究ではラミネートフィルムの機械的特性と, 異な る瓶口シール部形状の衝撃引張力におよぼす影響につい て明らかにするために最近, 食品品質保持等の理由から 液体包装袋で多く用いられている酸素打よび水蒸気のバ リア性を付与した多層ラミネートフィルムとバリア性を
付与していないラミネートフィルムを供試材に用いて， 引張および衝撃引張実験を行ない比較検討した。

\section{2 試験片および実験方法}

\section{$2 \cdot 1$ 試験片}

本実験に用いた供試材は市販のラミネートフィルムで, 一般液体包装袋用に使用されている酸素および水蒸気の バリア性を付与していないラミネートフィルム(1) [ナイロ ン $(\mathrm{NY})+$ ポリエチレン $(\mathrm{PE})+$ リニア・ローデンシティポ リエチレン改質物 $(\mathrm{XA}-\mathrm{S})]$ を $\mathrm{NY} / \mathrm{XA}-\mathrm{S}$ ，バリア性を 付与した多層ラミネートフィルム (2) [ナイロン (NY) + アルミナ蒸着 PET $(\mathrm{AE}-\mathrm{PET})+$ ポリエチレン $(\mathrm{PE})+$ リ ニア・ローデンシティポリエチレン改質物 $(\mathrm{XA}-\mathrm{S})]$ を $\mathrm{NY} / \mathrm{AE}-\mathrm{PET} / \mathrm{XA}-\mathrm{S}$, および (3) [ナイロン (NY) + アル ミ $(\mathrm{AL})+$ ポリエチレン $(\mathrm{PE})+$ リニア・ローデンシティポ リエチレン改質物 $(\mathrm{XA}-\mathrm{S})]$ を $\mathrm{NY} / \mathrm{AL} / \mathrm{XA}-\mathrm{S}$ とし，そ れぞれの厚さは $\mathrm{NY} 15 \mu \mathrm{m}, \mathrm{AE}-\mathrm{PET} 12 \mu \mathrm{m}, \mathrm{AL} 7 \mu \mathrm{m}, \mathrm{PE}$ $+\mathrm{XA}-\mathrm{S} 50 \mu \mathrm{m}$ で寸法形状を Fig. 1 に示す.

瓶口シール部形状のシール半径を $\mathrm{r}=7.5,10,12.5$, $13,14,15,20 \mathrm{~mm}$ と無限大 $\infty$ (通常の平シールで本研 究では無限大と表す）の 8 種類とした。その寸法形状を Fig. 2, Fig. 3 に示し, 一般に使用されている平シール および瓶口シール部形状の液体包装袋を Fig. 4 に示す.

ヒートシールはヒートシール装置を用いて, XA-S 面 同士を合わせて行い，食品包装用プラスチックフィルム

$\dagger \quad$ 原稿受理 平成 16 年 9 月 27 日 Received Sep. 27, 2004

* 大成ラミック森研究開発部 モ349-0293 埼玉県南埼玉郡白岡町下大崎, Development Dept. Taisei Lamick Co., Ltd., Minamisaitama-gun, Saitama, 349-0293

** 正会 員 埼玉工業大学工学部機械工学科 ₹369-0293 埼玉県大里郡岡部町普済寺, Dept. of Mech. Eng., Saitama Inst. of Tech., Ohosato-gun, Saitama, 369-0293 
試験法 ${ }^{12)}$ (JIS-Z-1707-1999) に基づき上下のヒートシール 板の間にラミネートフィルムを 2 枚に折りたたんで挟み 込みヒートシールした。

ここで, ヒートシール条件はヒートシール温度 $160^{\circ} \mathrm{C}$, ヒートシール圧力 $0.196 \mathrm{MPa}$, ヒートシール時間 $1 \mathrm{sec}$ である.

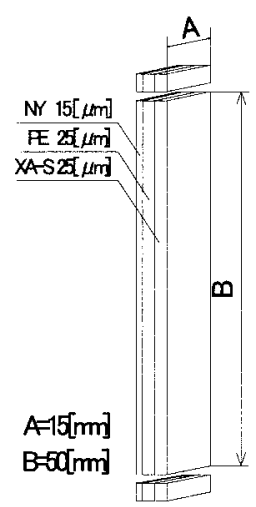

$\mathrm{NY} / \mathrm{XA}-\mathrm{S}$

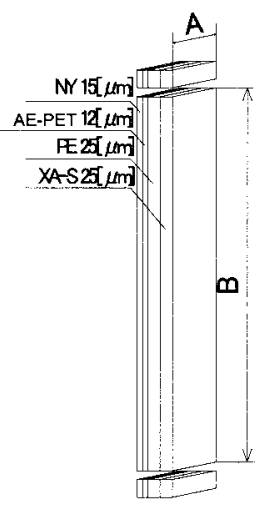

NY/AE-PET/XA-S NY/AL/XA-S

\section{$2 \cdot 2$ 実験方法}

本実験に用いた衝撃引張試験機は回転式衝撃引張試験 機でその構成図を Fig. 5 に示す。実験は回転式衝撃引張 試験機の上部チャックに試験片を固定し，試験片の下部 を専用フックに固定した後, 瓶口シール部形状のシール

Fig. 1. Laminate films.

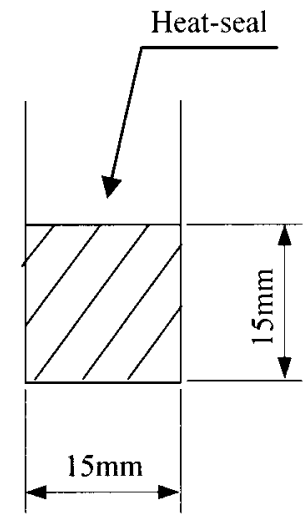

$r=\infty$ (flat seal)

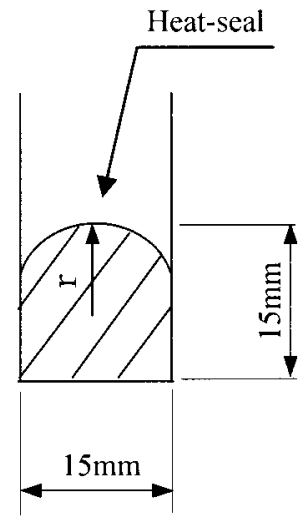

$\mathrm{r}=7.5,10,12.5,13$

$14,15,20 \mathrm{~mm}$

Fig. 3. Heat-seal form.

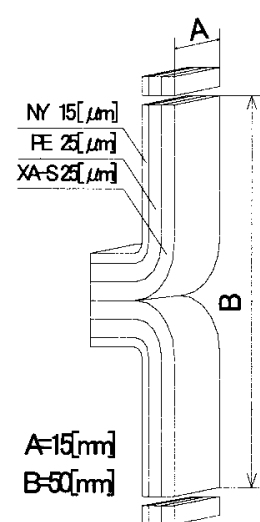

$\mathrm{NY} / \mathrm{XA}-\mathrm{S}$
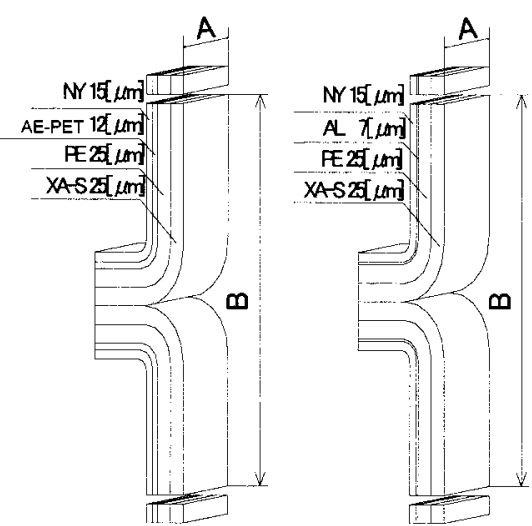

NY/AE-PET/XA-S NY/AL/XA-S

Fig. 2. Heat-seal laminate films.

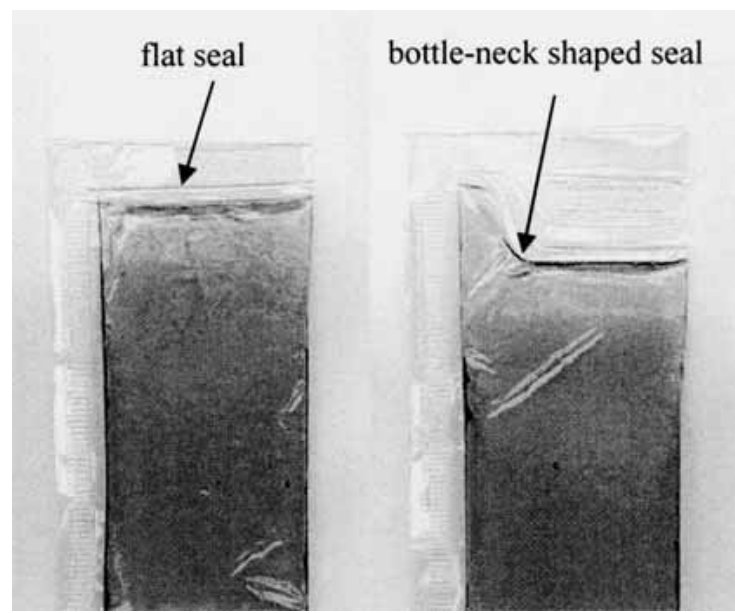

Fig. 4. Liquid package bag.

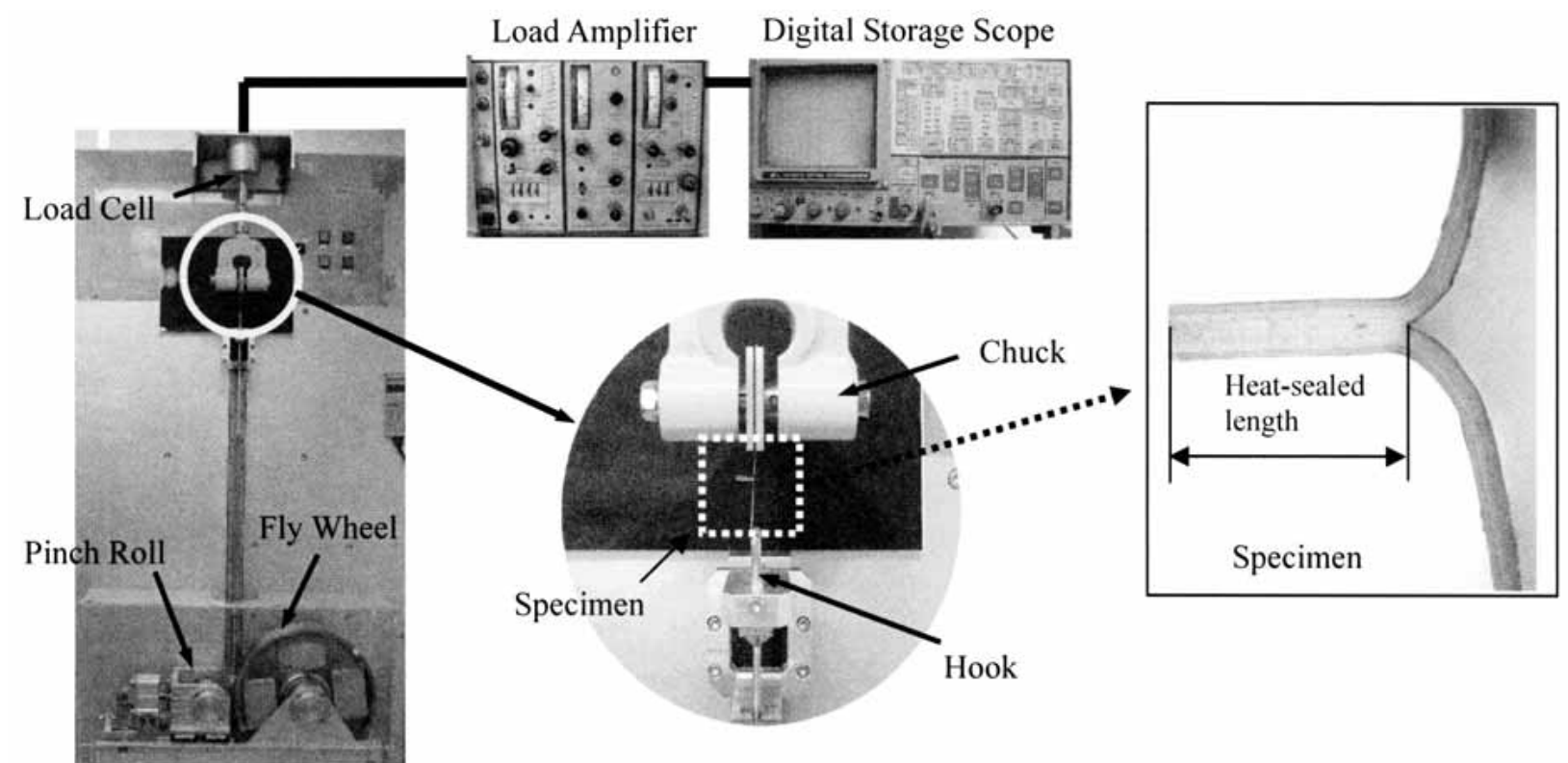

Fig. 5. Rotary impact tensile apparatus. 
半径を $\mathrm{r}=7.5,10 ， 12.5 ， 13 ， 14 ， 15,20 \mathrm{~mm}$ と無限 大 $\infty$ (平シール) の 8 段階に変化させて衝撃引張速度 $\mathrm{V}=$ $1.40 \mathrm{~m} / \mathrm{s}$, 䨌囲気温度 $23^{\circ} \mathrm{C}$ 一定で行った。

ここで，チャックとフック間の距離は一般に使用され ている液体包装袋のサイズから考慮し $50 \mathrm{~mm}$ とした。

試験片に生じる衝撃引張力は，ロードセル，ロードア ンプおよびデジタルストレージスコープを用いて衝撃波 形を記録し，波形のピークを測定した。

また，平シールおよび瓶ロシール部シール半径 $7.5 \mathrm{~mm}$ について引張にともなう温度変化を, 赤外線サーモグラ フィ（TH5100 NEC 社製）を用いて観察し，試験片に生 じる温度分布から応力集中部を確かめた。ここで，引張 速度は $\mathrm{V}=50 \mathrm{~mm} / \mathrm{min}$ ，䨌囲気温度は $23^{\circ} \mathrm{C}$ 一定である.

\section{3 実験結果および考察}

\section{$3 \cdot 1$ 応力ひずみ線図}

ラミネートフィルム NY/XA-S, NY/AE-PET/XA-S, $\mathrm{NY} / \mathrm{AL} / \mathrm{XA}-\mathrm{S}$ の 3 種類の機械的特性を明らかにするため に，Fig. 1 に示す試験片を用いて衝撃引張速度 $\mathrm{V}=$ $1.40 \mathrm{~m} / \mathrm{s}$, 䨌囲気温度 $23^{\circ} \mathrm{C}$ で衝撃引張実験を行った。そ の結果を Fig. 6 に示す.

Fig. 6 からわかるように 3 種類のラミネートフィルム は，ともにひずみの増加に伴い僅かな差はあるものの， ほぼ同じ傾向を示すことが確かめられた。

また各々の破断応力は $\mathrm{NY} / \mathrm{XA}-\mathrm{S}$ の場合 $58.2 \mathrm{MPa}$ ， $\mathrm{NY} / \mathrm{AE}-\mathrm{PET} / \mathrm{XA}-\mathrm{S}$ の場合 $65.9 \mathrm{MPa}, \mathrm{NY} / \mathrm{AL} / \mathrm{XA}-\mathrm{S}$ の場合 $55.1 \mathrm{MPa}$ で, NY/AE-PET/XA-S が最も高い応 力值を示すことがわかった。このことは $\mathrm{NY} / \mathrm{XA}-\mathrm{S}$, $\mathrm{NY} / \mathrm{AL} / \mathrm{XA}-\mathrm{S}$ に比し, NY/AE-PET/XA-S は延伸さ れたフィルムが 2 層（NYと $\mathrm{AE}-\mathrm{PET}$ ) 構成になってい ることから高い応力值を示したものと考える.

\section{$3 \cdot 2$ 瓶ロシール部形状が衝撃引張力におよぼす影響}

瓶口シール部形状による衝撃引張力に扎よぼす影響を 調べるため, 瓶口シール部形状のシール半径を $\mathrm{r}=7.5$, $10,12.5,13,14,15,20 \mathrm{~mm}$ と無限大 $\infty$ (平シール) の 8 段階に変化させてシールし衝撃引張実験を行った. その結果を Fig. 7 に示す.

Fig. 7 からわかるように衝撃引張力は NY/XA-S, $\mathrm{NY} / \mathrm{AE}-\mathrm{PET} / \mathrm{XA}-\mathrm{S}, \mathrm{NY} / \mathrm{AL} / \mathrm{XA}-\mathrm{S}$ ともに, 瓶ロシー ル部シール半径 $7.5 \mathrm{~mm}$ のときが最も低い值を示した。 瓶口シール部のシール半径 $7.5 \mathrm{~mm}$ の場合, 衝撃引張力

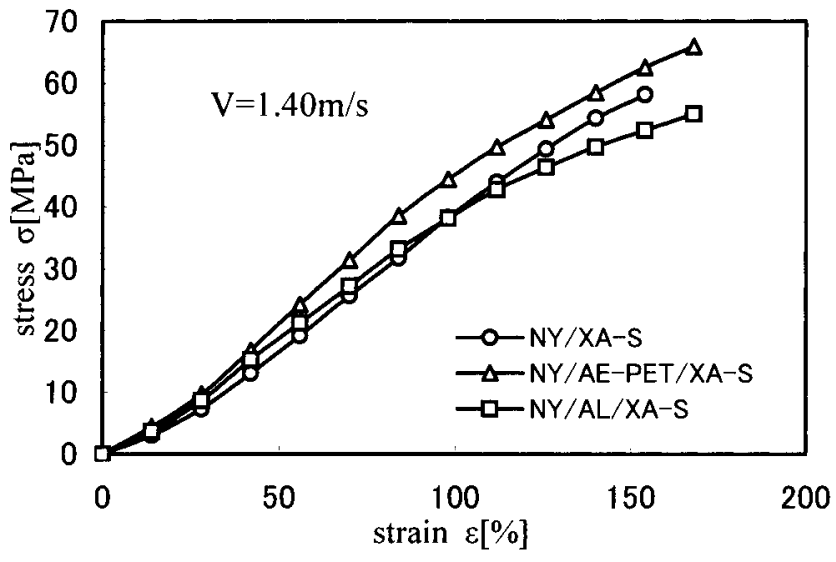

Fig. 6. Stress-strain curve.

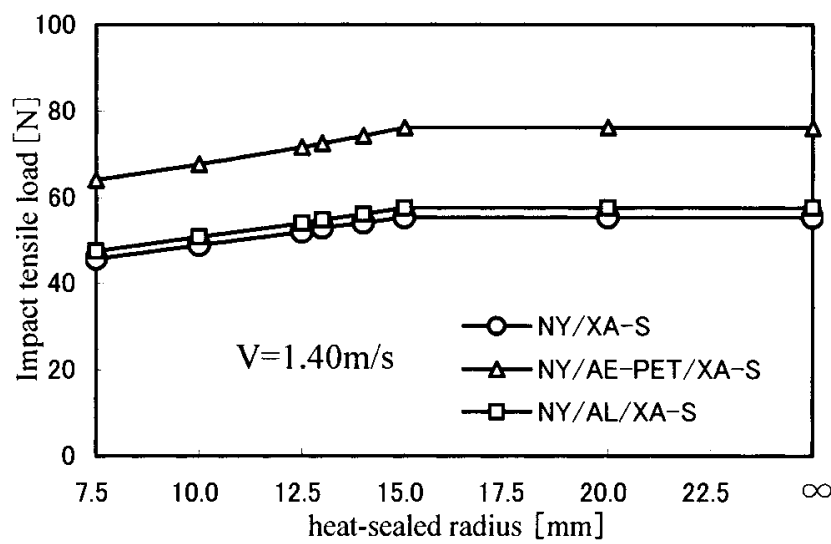

Fig. 7. Relationship between heat-sealed radius and impact tensile load.

は NY/XA-S では $45.7 \mathrm{~N}, \mathrm{NY} / \mathrm{AE}-\mathrm{PET} / \mathrm{XA}-\mathrm{S}$ では $64.0 \mathrm{~N}, \mathrm{NY} / \mathrm{AL} / \mathrm{XA}-\mathrm{S}$ では $47.5 \mathrm{~N}$ であり平シールの衝撃 引張力 $55.3 \sim 76.1 \mathrm{~N}$ に比し，16～17\% 低下することが 確かめられた。このことは, Fig. 8 (a), (b)からわかるよう に, 瓶口シール部のシール半径が $7.5 \mathrm{~mm}$ の場合, 平シー ルに比し, 瓶口シール部のシール半径が小さくヒートシー ルエッジの局部に最も衝撃引張力が集中することによる ものと考えられる

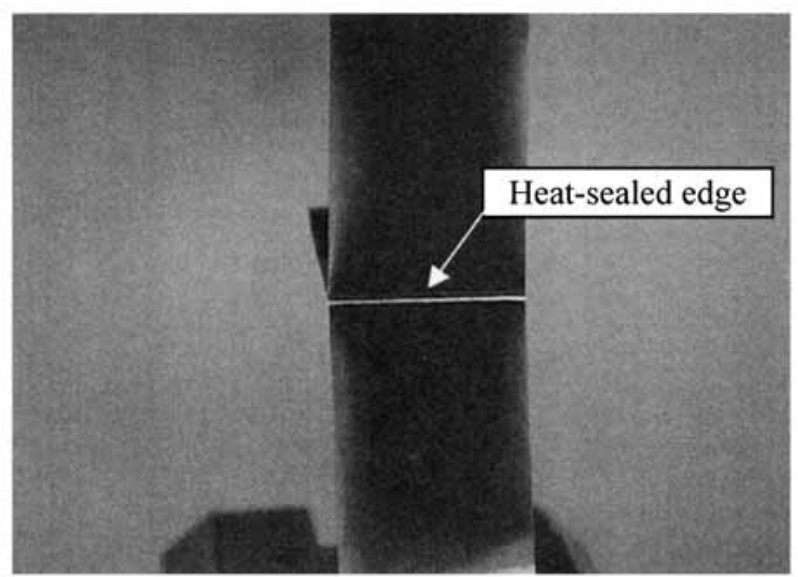

(a) $r=\infty$ (flat seal)

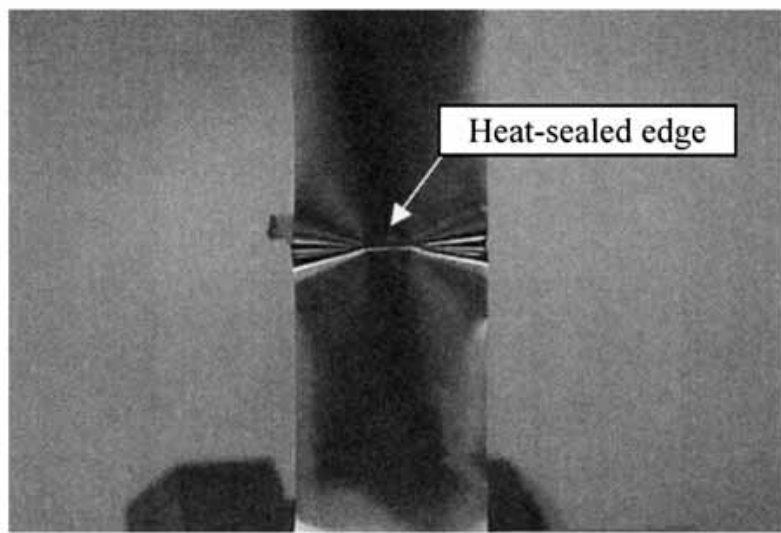

(b) $\mathrm{r}=7.5 \mathrm{~mm}$

Fig. 8. Heat-sealed edge. 
また, 瓶口シール部のシール半径が $7.5 \sim 15 \mathrm{~mm}$ 間で は瓶口シール部のシール半径の増加にともなって衝撃引 張力も増加し，良好な比例関係にあり，NY/XA-S， $\mathrm{NY} / \mathrm{AE}-\mathrm{PET} / \mathrm{XA}-\mathrm{S}, \mathrm{NY} / \mathrm{AL} / \mathrm{XA}-\mathrm{S}$ ともに, 同じ傾向 を示すことが確かめられた。瓶口シール部のシール半径 が $15 \mathrm{~mm}$ 以上になると，シール半径による影響を受ける ことなく衝撃引張力はほぼ一定值を示し平シールと同じ 值を示すことが確かめられた。

このことから，瓶ロシール部のシール半径は $15 \mathrm{~mm}$ 以 上あれば平シールと同等な衝撃引張力が得られ，十分有 効であり，瓶口シール部からの破袋を低減することが可 能となる.

\section{$3 \cdot 3$ 赤外線サーモグラフィによる温度分布の観察}

ヒートシール部の温度分布を明らかにするため, 䨌囲 気温度 $23^{\circ} \mathrm{C}$, 引張速度 $\mathrm{V}=50 \mathrm{~mm} / \mathrm{min}$ 一定で, 平シー ルおよび瓶口シール部シール半径 $7.5 \mathrm{~mm}$ の試験片に引張 荷重を負荷し，赤外線サーモグラフィを用いて温度分布 による応力集中部を観察した。 その結果を Fig. 9 に示す. Fig. 9 は NY/XA-S の場合であり，眓からわかるよう に, 平シールの場合, シール部先端で直線状に温度が上 昇しているのに比し, 瓶口シール部シール半径 $7.5 \mathrm{~mm}$ の

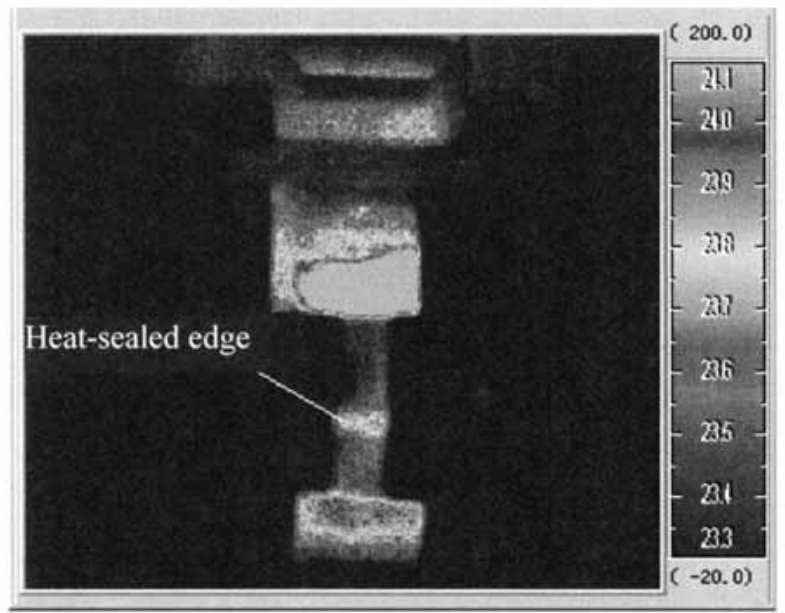

(a) Heat-sealed edge $r=\infty$ (flat seal)

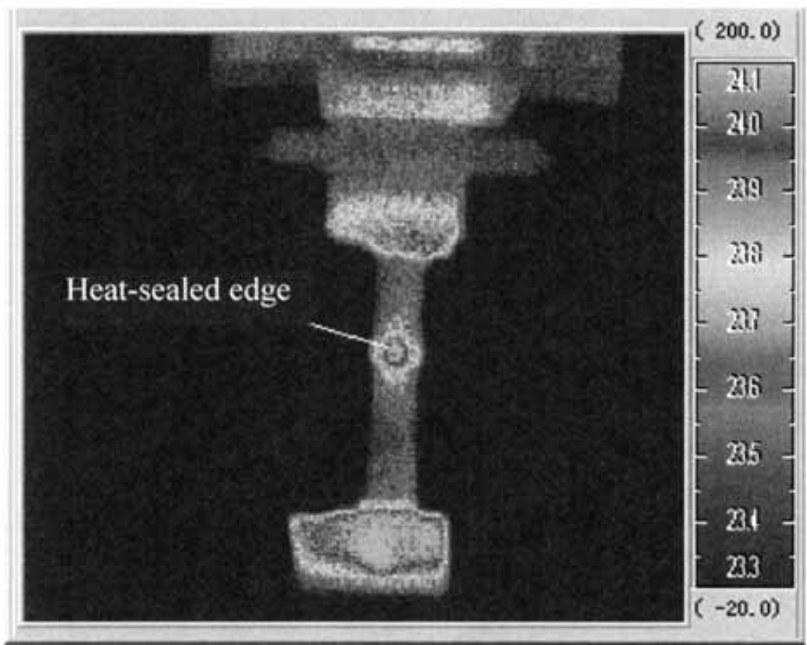

(b) Heat-sealed edge $r=7.5 \mathrm{~mm}$

Fig. 9. The temperature distribution observed by thermography.
場合はシール部先端で円形状に温度が上昇していること が確かめられた。また，平シール部先端の温度は $23.9^{\circ} \mathrm{C}$ であるのに比し, 瓶口シール部シール半径 $7.5 \mathrm{~mm}$ の場 合, シール部先端の温度は $24.1^{\circ} \mathrm{C}$ で平シール部の先端よ りも $0.2^{\circ} \mathrm{C}$ 高いことがわかった.

このことから, シール部先端に生じる引張応力は平シー ルの場合，線状に温度上昇しているのに比し，瓶口シー ル部シール半径 $7.5 \mathrm{~mm}$ の場合，ほぼ一点に温度が集中 していることが確かめられ，瓶口シール形状が衝撃引張 力に影響をおよぼしているものと思われる.

\section{4 結 論}

本研究では，食品品質保持等の理由から液体包装袋で 多く用いられている酸素打よび水蒸気のバリア性を付与 した多層ラミネートフィルムとバリア性を付与していな いラミネートフィルムを用いて実験を行い，ラミネート フィルムの機械的特性と瓶口シール部形状の違いによる 衝撃引張力におよぼす影響について検討した結果，以下 の知見が得られた。

(1) $\mathrm{NY} / \mathrm{XA}-\mathrm{S}, \mathrm{NY} / \mathrm{AE}-\mathrm{PET} / \mathrm{XA}-\mathrm{S}, \mathrm{NY} / \mathrm{AL} /$ $\mathrm{XA}-\mathrm{S}$ はともにひずみの増加に伴い僅かな差はあるもの の，ほぼ同じ傾向を示し，NY/AE-PET/XA-S が最も 高い応力值を示すことがわかった.

(2) NY/XA-S, NY/AE-PET/XA-S, NY/AL/ $\mathrm{XA}-\mathrm{S}$ ともに瓶口シール部シール半径 $7.5 \mathrm{~mm}$ の場合が 最も衝撃引張力は低く, 平シールに比し, 衝撃引張力は 16〜17\% 低下することが確かめられた.

(3) NY/XA-S, NY/AE-PET/XA-S, NY/AL/ $\mathrm{XA}-\mathrm{S}$ ともに, 瓶口シール部シール半径が $15 \mathrm{~mm}$ 以上あ ればシール半径による影響を受けることなく平シールと 同等の衝撃引張力が得られることが確かめられた.

\section{参 考 文 献}

1）二瀬克規，島本 聡，高橋 賞，日本機械学会論文集， A-60, 2891 (1994).

2 ）二瀬克規，島本 聡，高橋 賞，日本機械学会論文集， A-60, 2897 (1994)

3 ) 二瀬克規, 島本 聡, 高橋 賞, 青木博之, 非破壊検查 協会, 45，874（1996).

4）梅崎栄作，二瀬克規，青木博之，鎌田幸彦，非破壞検査 協会，52，303 (2003).

$5)$ E. Umezaki, Y. Kubota, A. Shimamoto and K. Futase, Proc. of ICCM-11, 547 (1997).

6 ) H. Aoki, A. Shimamoto, K. Futase and Y. Kamada, APCFS \& ATEM, 203, 467 (2001).

7 ) E. Umezaki, M. Shiobara and K. Futase, Resent Advances in Exp. Mech, 21 (1994).

8 ）青木博之, 島本 聡, 二瀬克規, 鎌田幸彦, 非破壊検査 協会 49，116（2000）。

9）二瀬克規, 島本 聡, 高橋 賞, 青木博之, 鎌田幸彦, 材料システム, 15，87 (1996).

10）二瀬克規，学位論文，5（1998）.

11) K. Futase, A. Shimamoto, S. Takahashi and H. Aoki, NDT \& SSM, FENDT'92, 632 (1992)

12）日本規格協会編，“JIS ハンドブック プラスチック”, p.894 (1999). 